\title{
EU-AFRICA RELATIONS: TOWARDS A NEW COMPREHENSIVE STRATEGY WITH AFRICA. BETWEEN A ROCK AND A HARD PLACE
}

The European Union's relations with Africa are at a crossroads, between a rock and a hard place. A new strategic partnership is in the making and the entire process raises a number of fundamental questions about its future. The complexities facing the EU and its African partners encourage curiosity and reflection about the nature of the new partnership. Relations between the European Union and Africa have been developing for over sixty years and both sides seem to be ready and willing to strengthen and modernize their partnership.

A few days after her election as President of the European Commission, Ursula von der Leyen embarked on her first official trip, a trip to Addis Ababa, the capital of Ethiopia and the headquarters of the African Union. It was symbolic and in line with her calls for a 'comprehensive strategy for Africa' (Von der Leyen, 2019). The visit was supposed to announce to the world, specifically to African leaders and other actors like China, Russia, the US and the Gulf states, that the EU was making Africa a priority, and was ready to work with the African Union "within the spirit of a true partnership of equals" (Herszenhorn, 2019: 1). Von der Leyen promised a comprehensive strategy for Africa by March 2020.

It was, by all means, a timely visit given the waning influence of Europe in Africa in contrast with an increasingly assertive China, Russia as well as other players within the African continent. By 2009 China had become Africa's biggest trading partner, and Chinese influence has only increased over the last few years as many African countries are turning to China for aid, trade and infrastructural development (Ighobor, 2013: 2). Yet another reason EU-Africa relations are at a crossroads is that the Cotonou Agreement, which EU-Africa relations are based on, was terminated in February of this year. It was concluded between the European Union and its member states and a group of African, Caribbean and Pacific (ACP) states in 2000 for a duration of twenty years. Talks on the successor of the Cotonou Agreement have begun, but have stalled. Negotiating a postCotonou agreement is a slow and arduous process, between a rock and a hard place.

The overall aim of this article is to provide an insight into the EU's new partnership with Africa and the research explores its constitutive elements and principal characteristics: its nature and scope, actors, legal bases, and different ways both sides are going 
to present the new agreement to their respective constituencies. Special attention will be given to normative and rhetorical commitments made by the European Union and the African Union towards each other. The article will look into the evolution of the EU's relations with Africa since the end of colonization, will account for the state of this relationship today and consider what will happen to this relationship in the future. The way this research is pursued combines a number of methods. It involves the analysis of primary sources - the texts of instruments regulating the EU's relations with Africa, secondary sources, documentary analysis as well as comparative, contextual and historical analysis.

The article is divided into five interrelated sections. The first deals with the EU-Africa partnership in a historical perspective, with a brief examination of the antecedents of the Cotonou Agreement. The second section provides a detailed critical analysis of the current EU-Africa partnership with particular attention being paid to the Cotonou Agreement itself, as well as the 2007 Joint EU-Africa Strategy. Section three - what next - looks into the new partnership, and the post-Cotonou agreement: the shape it is likely to take, the negotiating positions of both sides, the hurdles they have to overcome. However, a detailed, critical analysis of the post-Cotonou agreement will only be possible after it is concluded and published. The purpose of section four is to identify the most critical, contentious issues and processes, selected for their particular relevance, that are likely to shape the positions of both sides and, at the end of the day, the shape of their new partnership. In the final concluding section the article considers whether and to what extent the current model of EU-Africa partnership is likely to be enhanced, strengthened and modernized or whether it will remain largely 'as is' with only some rhetorical and superficial modifications and amendments made.

\section{EU-AFRICA PARTNERSHIP. AN OVERVIEW}

The European Union has a long history of relations with Africa and Africa has always been a strategic partner for the European Union. The current phase of the EUAfrica partnership combines the elements of continuity and change of its content, legal bases, institutions as well as practices. The main purpose of this section is to identify the pillars of the EU-Africa partnership and the way they count in today's negotiations. It is a selective overview meant to illustrate that from the beginning EU relations with Africa were based upon the concept of partnership (Farrell, 2006: 19) and that the partnership in question is based on solid and long-standing foundations that, somehow and despite obvious shortcomings and reservations, withstood the test of time. Without a doubt, many of the issues negotiated today have their roots in earlier agreements.

\section{Historical antecedents of the EU-Africa partnership}

Relations between the European Union and Africa extend back many decades through the Treaty of Rome, the Yaoundé Convention and its successor four Lomé conventions (1975, 1979, 1984 and 1989). 
The Treaty of Rome included a number of provisions which allowed the extension of the customs union to the then colonies of the European Economic Community member states some of whom wanted to retain formal links with former or current dependencies. This was, for instance, a priority for France (Holland, 2002: 25; Hurt, 2004: 157). Articles 131 and 136 of the Treaty of Rome served as the legal basis for Europe's relations with African states along the lines of the twin principles of 'trade and aid' within the larger framework of development. While article 131 called for member states to 'associate with the community' those countries which were not European but had 'special relations' with some of its members states with the aim of promoting 'the economic and social development', Article 136 authorized the European Economic Community (EEC) to negotiate a treaty with those 'non-European states' and associate them with the EEC. For some, it meant the continuation of historical ties and colonial dependency (Holland, 2002: 27).

On the African side, the Treaty of Rome was criticized by the then leader of Ghana and pan-Africanist Kwame Nkrumah. Just a few weeks after the declaration of Ghana's independence in 1957, he called it a neo-colonial agreement, comparable to the 1885 Treaty of Berlin which formalized the colonization of Africa (Zartman, 2016; Gruhn, 1976: 244). Even to those who were critical of Nkrumah's comparison, the intrinsic link between African independence and European interdependence could not be ignored. The insistence by France and Belgium to link their colonies to the European Economic Community was no secret (Zartman 2016: 6-9; Kotsopoulos, 2017: 1). By linking the economies of the Belgian and French colonies to those of the EEC member states through trade preferences, the Treaty of Rome laid the foundations of the relationship between Europe and Africa (Kotsopoulos, Mattheis, 2018: 445; Whiteman, 2017: 35).

The Yaoundé Convention was signed on July 201963 in Cameroon between the European Economic Community (EEC) and a group of independent African states - the AASM (Associated African States and Madagascar) - and replaced by another Yaoundé Convention in 1969. The negotiations for the first Yaoundé Convention saw 18 African states express their desire 'to consolidate their privileged position' with the Community recognizing little or no difference from the overseas countries and territories (OCTs) included in Part IV of the 1957 Treaty of Rome (Huber, 2013: 128).

However, negotiations leading up to the second Yaoundé Convention of 1969, were contested by a number of EEC member states, such as West Germany and the Netherlands, who showed little interest in continuing the association and adopted a more globalist stance of providing assistance to all developing countries. Moreover, with the UK's application for accession in 1961, Commonwealth territories like Nigeria, Kenya, Uganda and Tanzania began knocking on the EEC's door. Ultimately, all of them concluded association agreements with the EEC. Nigeria in 1966 in Lagos and Kenya, Uganda and Tanzania in 1969 in Arusha. While the latter was successfully ratified, the former did not come into force because of the 1967-1970 Nigerian civil war (Frisch, 2008: 5).

The Yaoundé Conventions were often interpreted as representing the desire of the European states to retain the economic links and access to natural resources and raw materials they had previously enjoyed under colonial rule, and as a "poorly disguised 
extension of French foreign and colonial policy" (Holland, 2002: 31-32). Holland underlines that it linked Europe to a small group of African states and it sowed "the seeds of 'Europe's future piecemeal approach" to its relations with the Third World (Holland, 2002: 30). The Yaoundé Conventions were criticized by pan-Africanist leaders like Touré of Guinea and Nkrumah of Ghana as neo-colonialist. It is no surprise that the shadow of colonialism and neo-colonialism continues to matter in current negotiations.

The successor of the Yaoundé Conventions, the Lomé Convention was concluded in February 1975 in Togo between the European Economic Community and a group of 71 African, Caribbean and Pacific states. It was, by all means, an innovative, watershed arrangement that restructured and expanded - following the British accession - the European Communities' relations with African states to include states from the Commonwealth Caribbean and Pacific. Holland described it as a replacement of one acronym with a new configuration (Holland, 2002: 34); Hurt, as a breakthrough for the ACP states (Hurt, 2004: 158). In short, it was a preferential trade agreement combined with elements of political dialogue. Successive Lomé II (1979), III (1985) and IV (1989) conventions expanded trade and political relations and created an institutional framework for dialogue among the participating states.

Lomé Conventions laid the foundations of the EU-Africa partnership and its institutions. A commitment to an equal partnership between Europe and ACP countries was the most distinctive feature of the Convention (Holland, 2002: 34). Still, Lomé arrangements did not overcome the asymmetrical trading relationship between the EU and Africa and unbalanced nature of their political dialogue, despite repeatedly referring to the spirit of solidarity. It also failed to substantially increase the level of development in Africa (Farrell, 2006: 20). The asymmetrical nature of the EU-Africa partnership continues to burden the African partners.

\section{From Lomé to Cotonou}

The four consecutive Lomé Conventions continued to govern relations between the European Union member states and the ACP states for twenty five years. Montoute, in her description of the sequence of events which led to the transition from Lomé to Cotonou explains that by the 1990s, economic thought had shifted from import substitution industrialization to export led industrialization as well as from the doctrine of non-reciprocity to reciprocity in trade relations. With the end of the Cold War, European states were readjusting their national interests (Montoute, 2017: 8). Also, the World Trade Organization (WTO) declared in 1997 that the Lomé non-reciprocal agreements were incompatible with the WTO's reciprocity-based rules (McQueen, 1998: 671). As Montoute argues, these new WTO rules have been largely shaped by the powerful players which included EU countries (Montoute, 2017: 18). Part of this new development thinking linked 'good governance' with 'sustainable development' even though it was evident that the EU and ACP group had different views on development - the former insisting on trade liberalization and the latter on development enablers (Montoute, 2017: 12). 
In such circumstances Lomé, primarily a framework for development, could no longer serve the interests of both sides and had to expand in scope and substance. Therefore, the Cotonou Partnership Agreement (CPA), which was signed in June 2000, went several steps further to include cooperation in the fields of, inter alia, gender issues, climate change, migration, labor and organized crime. It also adopted a view of multidimensional development and carved out an area for civil society in the development process (Montoute, 2017: 18-21).

Many analysts agree that the Cotonou agreement represents a radical paradigm shift in relations between the EU and ACP states, "a new departure in terms of both its substance and approach to Africa-EU relations" and "reasserts, at the rhetorical level, the principle of partnership as the defining element of EU-ACP relations" (Farrell, 2006: 16 and 21). Others emphasize its role as a model for North-South cooperation (Zajączkowski, 2005).

\section{EU-AFRICA PARTNERSHIP TODAY. NORMATIVE FRAMEWORKS}

Today, EU's relations with Africa are governed primarily by the 2000 Cotonou Partnership Agreement. However, yet another, distinct framework for EU-Africa relations is provided by the Joint Africa-EU Strategy (JAES) adopted by 80 African and European Heads of State and Government at the Lisbon Summit in 2007. Combined, both instruments outline Europe's relationship with Africa in the economic, political and development dimensions as well as issues relating to peace and security, human rights, migration and democracy.

As a footnote, it must be acknowledged that not all African states participate in the Cotonou based EU-ACP partnership. North African states - Morocco, Algeria, Tunisia Libya and Egypt are all included in different partnerships - the Euro-Mediterranean partnership (EUROMED or the Barcelona Process) and in the European Neighborhood Policy. Their relations or partnerships with the EU are based on different sources - the 1995 Barcelona Declaration, a network of association agreements as well as EU legislation. Ultimately, EU relations with Africa and African states are highly fragmented and encompass a variety of partnerships.

The Cotonou Partnership Agreement between the EU and its member states and sub-Saharan African, Caribbean and Pacific states, was signed in 23 June 2000. The CPA has been revised twice, in 2005 (CPA II) and 2010 (CPA III). It is divided into three pillars/action areas: development co-operation, trade and political dialogue. Democracy, good governance and respect for human rights are also strongly emphasized (Kingah, 2006: 59). The CPA gives free access to the European market to $99.5 \%$ of products originating from ACP states and its goal is to eradicate poverty in ACP states by integrating them into the world economy.

CPA II, signed in 2005, introduced five key areas of consideration: security (relating to the fight against terrorism and mercenary activities), political dialogue (relating to pragmatism and procedural flexibility in terms of the persons able to participate in dialogue), transparency (greater emphasis on the fight against corruption), widening of the list of beneficiaries and access to funds, and increased social responsibility 
(Kingah, 2006: 60-68). CPA III, signed in 2010, intended to find a balance between differentiation and unity within the ACP group. It was evident that with the entry into force of the Lisbon Treaty in 2009 - a treaty which prioritized EU-AU relations - and the establishment of the European External Action Service which was given the responsibility of handling bilateral relations with ACP countries, the exclusivity of the ACP group was in danger (Bartelt, 2012: 1).

The Cotonou Agreement terminated on February 29 this year. It was expected to be replaced by a new, post-Cotonou agreement negotiated since 2018. However, not all went as planned and a decision was taken to extend its application without any changes to December 2020. This, quite unusual, surprising and ad hoc decision, described as a 'transitional measure' was taken by the two parties on February 14, 2020. Thus, negotiations on the post-Cotonou agreement are still under way (European Commission - Press Release, 14 February 2020).

The other, 'continental', partnership this paper focuses on, represents yet another EU partnership with Africa. It was during the second EU-Africa summit meeting in 2007 in Lisbon that 80 African and European Heads of State and Government adopted the Joint Africa-EU Strategy, The document was meant to "reinforce and elevate the Africa-EU political partnership at all levels" by providing "an overarching long-term framework for Africa-EU relations" (The Africa-EU Strategic Partnership, 2007).

Generally, its aim is to strengthen and promote economic cooperation, sustainable development, prosperity, peace and security, democracy and solidarity between and within both continents. The JAES is a constantly evolving set of institutional arrangements. For instance, the $5^{\text {th }}$ AU-EU summit in Abidjan in 2017 identified four strategic priority partnership areas: migration and mobility, economic opportunities for youth, peace and security, and cooperation and governance (Declaration, African Union-European Union Summit 2017). A new EU joint strategy with Africa is being negotiated as well. It is expected to be endorsed by the next, $6^{\text {th }}$ EU-AU summit meeting in October 2020 in Brussels.

What has been presented so far illustrates the fact that the EU's partnership with Africa is visibly bifurcated and fragmented, consisting of - if we put the EURO-Mediterranean partnership aside - two frameworks, two sets of institutions and two sets of legal instruments that govern relations between the EU and Africa. One, between EU and its member states and a group of African (and Caribbean and Pacific) states, governed by the Cotonou Agreement, the other, between the EU and Africa, leaning towards EU-AU partnership, governed by the 2007 Joint Africa-EU Strategy. Together, these two sets of documents form the basis of today's African-EU partnership. Both include political, economic and development dimensions and both, perhaps not by chance, are presently on the negotiating table.

To complete the picture of normative frameworks which shape EU-Africa relations, yet another strategy document has to be mentioned. It is the European Union's 2005 Strategy on Africa which combined with a series of more specific and geographically limited EU common strategies - the 2000 Common Strategy on the Mediterranean Region, the 2011 EU Strategy for Security and Development in the Sahel, and the EU Strategy on the Gulf of Guinea adopted by the Council of the European Union in 2014, forms a real maze of instruments and institutions. Finally, a network of EU's 
agreements with African regional integration organizations, such as the Economic Community of West African States (ECOWAS) has to be taken into consideration as contributing to the fragmentation of the African side of the partnership.

How can such a complex and fragmented system work in practice? Lopes argues that this plethora of institutional arrangements has not only been complex, controversial, contradictory and fragmented but has also been overlapping and counterproductive (Lopes, 2019). Perhaps Europe and Africa need a new partnership which could focus on the new realities in both regions and overcome the difficulties ensuing from its fragmentation. The fact both legs of the EU-Africa partnership are currently on the negotiating table, offers a unique opportunity to address this.

The European Commissioner for International Partnerships, Jutta Urpilainen, commented in February 2020 that:

"The proposals set out build on a growing momentum in EU-Africa relations. [...] 2020 will be a pivotal year in living up to our ambition of an even stronger partnership with Africa, our natural partner" (European Commission - Press Release, 9 March 2020).

However, the record of the partnership is by all means mixed, indicating that all is not well. As was already mentioned, China has become Africa's biggest trading partner and Chinese influence has only increased over the last few years as many African countries are turning to China, rather than EU, for aid, trade and infrastructural development. Kaczmarek is right to acknowledge that "the new Chinese narrative is attractive for Africa (the campaign 'tell China's stories well'), which is further facilitated by the anti-colonial and equality-driven discourse of China and the fact that it makes no demands in terms of democracy and human rights" (Kaczmarek, 2019: 157). The Chinese model of economic development is increasingly attractive to African leaders (Kopinski et al., 2011).

Ranier Sabatucci, the EU's ambassador to the African Union has attributed this waning influence in Africa to Europe's fixation on migration. Over the last couple of years, the EU's focus on Africa has been aid in exchange for a commitment to accept the return of economic migrants. While focusing on this, the EU is failing to see Africa for what it is becoming and missing out on the opportunity to build stronger ties with Africa. The EU as such needs to re-conceptualize and re-strategize its position on Africa as a continent that is coming of age (Nielsen, 2019: 1).

Other commentators, however, have been quick to offer a sharper take on EU-ACP relations, particularly with the African ACP bloc. Orbie, for example contends that in the 1970s Europe's relations with Africa were innovative and because of this, Europe played a central role in shaping Africa's trade with the rest of the world, always leading the way (Orbie, 2007: 297-299). However, the EU's policies have shifted from a development-oriented to a value-based approach (Ibidem: 303). After evaluating the EPAs, Storey concludes that the EU's trade policy towards the ACP is guided both by corporate realpolitik goals and normative interests even though the EU prefers to present itself only as a normative actor. The issue is that the EU's commitment to the neoliberal agenda does not necessarily correspond to Africa's developmental needs (Storey, 2006: 342-343) In fact, despite some benefits accrued by African states from 
their relationships with Europe, these relations have always been asymmetrical and as such have hindered Africa's regional integration and development efforts (Akokpari, 2017: 56). In essence, the EU is using its leverage to force African countries to agree with its policies which have the unintended consequences of preventing regional integration (Stevens, 2006: 443). These commercially motivated bilateral trade agreements, it is asserted, have adverse consequences on developing countries (Young, Peterson, 2013: 514-515).

Additionally, Langan argues that the EU's moral economy is a cover story - i.e. the utilization of moral norms only legitimizes and self-rationalizes its geopolitical interest and commercial gain in its external relations with external 'partners', in this case African ACP states (Langan, 2012: 252). It may be that the EU-African partnership model is simply symbolic (Arts, Dickson. 2004: 1-3) or perhaps it is a case of disjointed nature of EU policy-making at work, characterized by serious tensions and conflicts between the EU Commission, EU Parliament and EU Council which makes the stance of the EU fundamentally ambiguous (Elgström, Pilegaard, 2008: 364).

It may be concluded that many writers are of the opinion that EU's relations with Africa have not lived up to what they promised to be. Whatever the case may be, the EU-African relationship is here to stay - at least for the foreseeable future - and the task at hand should be one to mitigate the shortcomings while capitalizing on the future potential and mutual benefits of an agreement 'for equals and between equals'.

\section{NEW PARTNERSHIPS}

The two EU-Africa partnerships - the EU-AU partnership and the partnership under the aegis of ACP - are being negotiated between the parties and their ultimate shapes will not be published before October 2020 and December 2020 respectively. Obviously, the negotiating directives (EU) and mandate (ACP) are known and were published long ago, however the details from the around-the-table negotiations are scarce and patchy.

\section{From Cotonou to ....Cotonou}

The Cotonou Agreement was concluded twenty years ago for twenty years. Thus, the core objectives of the partnership have to be reviewed to adapt to new realities and to accommodate recent trends and initiatives that surfaced in the meantime, including, for instance, the UN 2030 Sustainable Development Goals, the New EU Consensus on Development, the Global Strategy on EU Foreign and Security Policy as well as the African Union's Agenda 2063, the blueprint and master plan for transforming Africa into the global powerhouse of the future, rooted in the concept of pan-Africanism.

The new partnership is expected to act as a powerful tool to strengthen the EU's relations with its partner states as a group, as well as with each "region" - Africa, the Caribbean and the Pacific. The proposed new structure consists of a general, foundational agreement containing a list of key values, principles and objectives common to 
the EU and Africa, the Caribbean, and the Pacific as well as three regional partnerships (EU-Africa, EU-Caribbean, EU-Pacific) in the form of specific protocols focused on group specific priorities. These three "regional" protocols will allow for a greater role of the relevant regional organisations in the establishment and management of future regional partnerships - in the case of Africa - the African Union. At the same time, this new partnership is to enhance the role of the African sub-regional organisations such as ECOWAS and SADC.

The specific priorities proposed for the EU-Africa partnership focus on achieving peace and stability, managing migration and mobility, consolidating democracy and good governance, unleashing economic opportunities, reaching human development standards, and addressing climate change. The new partnership is expected to rely on principles of subsidiarity and complementarity. It is also expected to be a system of multi-level governance.

The EU chief negotiator is the Commissioner for International Partnerships, Jutta Urpilainen. The ACP negotiating group is composed of representatives from the three regions (Africa, the Caribbean and the Pacific) and is led by the Hon. Robert Dussey, Minister for Foreign Affairs, Cooperation and African Integration of Togo. The new agreement is to be concluded for twenty years and may be extended for a maximum of five years.

The latest round of negotiations in February 2020 was reported to be 'productive', 'cordial' and that the discussions were "frank and direct." At the same time the need "to accelerate the talks to reach a final agreement soon" was expressed by the EU negotiator and, ultimately, the decision to extend the application of the current Cotonou Agreement was taken (European Commission - Press Release, 14 February 2020). All of these clearly indicate that the talks are complicated, arduous and that not much progress has been made so far. There seems to be no risk of breakdown and a lengthy and laborious negotiating process, the details stage, will continue with no guarantee of meeting the self-imposed deadline of December 2020. The momentum of the negotiations may, perhaps, be regained after the October EU-Africa Summit meeting in Brussels.

\section{A New EU strategy with Africa}

The other partnership, the one based on the 2007 Joint EU-Africa Strategy, is also on the agenda of several European institutions. It is meant to further develop EU's "continent-to-continent" relationship with Africa. A new joint strategy is expected to be endorsed at the European Union - African Union Summit in October 2020.

In March 2020, the EU Commission produced a Joint Communication to the European Parliament and the Council, an outline of the proposed new comprehensive strategy with Africa (Joint Communication, 9 March 2020). The document acknowledges the potential of Africa's economic expansion - in 2018, six of the world's fastest growing economies were African states - and opportunities which may arise from new African projects: the African Union's Agenda 2063, the African Visa-Free trade area, the African Continental Free Trade Area (AfCFTA), a single African Air Transport Market, and a single African Digital Market. At the same time, it takes cognizance of 
a number of challenges facing the African continent, ranging from a high number of the world's most fragile countries (thirty-six), hosting 390 million people living below the poverty line, to governance challenges and civil conflicts, and not least to the effects of climate change. The goal of this strategy is a partnership based on a clear understanding of mutual responsibilities and interests between Africa and Europe, one, which reflects the 'comprehensiveness and maturity' of their historic relationship.

The Commission supplied a list of five key areas, or area specific partnerships to be acted upon: partnership in green transition and energy access, partnership in digital transformation, partnership in sustainable growth and jobs, partnership in peace and governance and a partnership in migration and mobility. The report acknowledges that both partners will have to work together at the global level to strengthen the rule-based multilateral system with the UN at its core, as well as their bilateral relations. The success of the new strategy will be measured by concrete outcomes and tangible results for citizens on both continents.

Critical discussions on EU-AU relations are often dominated by two arguments: one that the nature of this relationship is neo-colonialist and exploitative and the other one that attributes its failures to poor African governance (Kotsopoulos, Mattheis, 2018: 446). The proposed comprehensive strategy seems to take cognizance of both of them and in many different ways offers to alleviate both concerns.

The new strategy promises to provide African partners with up to 60 billion Euros in sustainable investments as part of the EU's efforts to enhance infrastructural and financial development. This, at least, recognizes the need for sustainable and reliable investment in Africa which will eventually engineer development (Ibidem: 445-446). Furthermore, the strategy recognizes that security and development are sustainable only if rooted in democratic principles, respect for human rights and gender equality. As such, supporting good governance, the rule of law and human rights are essential. If properly implemented, the concerns of those who criticize the EU's wilful 'blind eye' towards African rulers who have a record of undemocratic practices in exchange for favourable trade policies might be alleviated. The strategy also acknowledges the changing nature of security in Africa while at the same time supporting African ownership of security measures aided by the European Peace Facility. It calls for both continents to step up their partnership on peace and security.

Over the last couple of years, Europe's emphasis on migration was not well received within African circles. The strategy admits the multidimensional nature of migration and calls for a "balanced, coherent and comprehensive approach to migration and mobility guided by principles of solidarity, partnership and shared responsibility," even encouraging the EU to take actions to "resettle persons in need of international protection in Europe." The EU is 'talking the right talks', but it remains to be seen how these proposals will be translated into real action and whether this will benefit Africa as much as it will Europe (Joint Communication, 2020).

We note that the language of the document is carefully crafted to distil any fears of a potential asymmetrical relationship, often referring to the relationship as a partnership. Given the long history of asymmetrical relations, this may not be sufficient to convince sceptics that Europe is willing to treat Africa as an 'equal partner', but it certainly offers a valuable starting point. 
The Communication was described by Commissioner Urpilainen as the first step in a process. It was also reported that the partnership through a new EU strategy with Africa was on the agenda of the 'Commission to Commission' meeting of the European Union and the African Union in February 2020 in Addis Ababa. The meeting, attended by the President of the EU Commission Ursula von der Leyen, Vice-President Josep Borrell and a group of nineteen European Commissioners focused, inter alia, on renewing the EU partnership with Africa (EEAS, Press Release, 28/02/2020). This EUAU format will undoubtedly continue to be used for consultations before the October EU-Africa summit meeting. The outbreak of the coronavirus pandemic may, however, force the Unions to change plans.

\section{AFRICA IS COMING OF AGE}

The time has come to identify the critical, contentious issues that have been straining EU-Africa relations, some of which have already been settled, and some of which are still pending and will continue to antagonize the parties.

Africa has always been a strategic partner for the European Union. However, even a cursory glance through relevant literature - there is a rapidly growing body of literature on EU's relations with Africa and African relations with Europe - as well as policy statements on both European and African sides, reveals that many issues, including fundamental questions such as the future shape of the partnership, its asymmetrical character, equality of the parties etc. remain contentious and deeply divisive. Therefore, how will this partnership, or partnerships work in the future? What does it do well? What shape it is likely to take? To what extent does its development reflect the values and expectations of both sides? Who exactly are those 'sides' in the first place and what are they going to be? Is it likely to remedy the weaknesses of the past models of partnership? These are just some of the questions the parties have to address, and to a certain extent already do take into consideration. The EU-Africa partnership does not stand still.

\section{EU-Africa vs. EU-ACP Partnership}

One of the overarching issues that is likely to dominate the negotiations and the future shape of the partnership is the fact Africa is coming of age. The new partnership will continue to be, like under the Lomé and Cotonou agreements, the partnership of the European Union and its member states with a group of ACP states. Many African leaders are hoping for an agreement focused on Africa, on a continent-to-continent basis, rather than one with a broader group of ACP states. For them, being put in the same category as small island states from the Caribbean and the Pacific, is, by all means, degrading and does not reflect the growing importance of Africa in the world economy and as a source of migration to Europe. Another argument used in favour of a Europe to Africa partnership is that the ACP group of states does not include North African states. For now, they continue to be partners of the European Union under the Euro-Mediterranean partnership. 
Notwithstanding the misgivings of many African leaders, scholars comment that Europe's attention is increasingly focused on reinforcing its partnership with Africa and less on the ACP. Laporte, for instance, refers to little or no prominence given to the ACP when the Joint EU-Africa partnership was forged in 2007 in Lisbon, or the EEAS priorities formulated (Laporte, 2012: 3). Carbone contends that within the EU there already are signs of declining commitment towards the EU-ACP relationship and a preference for a continent-to-continent approach (Carbone, 2013: 749). Furthermore, the gradual shift from the ACP to Africa on issues such as peace and security, mobility and migration, democracy and good governance, and human rights, areas which have consecutively featured strongly in the 2014 and 2017 AUEU summits is an indication of the ACP losing some political significance and clout (Montoute, 2017: 19). This would explain the growing tensions between the AU and ACP negotiators as they struggle to dominate talks with the EU (Carbone, 2018: 481-482).

For the moment, however, the EU-ACP partnership continues to govern the relations between the European Union and its member states and a group of ACP, including most of the African states. Africa's coming of age is, perhaps, the reason the future post-Cotonou agreement will include, on top of a general, overarching part applicable to all ACP states, three special partnership strategies one of which will define specifically EU's relations with the ACP African states. The ACP, an international actor created by the Lomé Convention that dominated Europe's perspective on the Third Word (Holland, 2002: 40) will soon lose its homogeneity. The new proposed partnership will clearly mark a shift away from the unity of ACP states.

\section{The African Union: between Pan-Africanism and fragmentation}

Yet another dimension of Africa's coming of age is the evolution of the African Union. As mentioned before, the new 'continental' partnership with Africa will refer to the African Union - AU-EU partnership. This, at first glance, may be seen as fairly unimportant, however, it is far more than purely symbolic. The African Union, officially launched in 2002, is gradually becoming a continental union in its own right. Farrell, for instance, points out that "contained within the Constitutive Act of the African Union are the key ideas concerning continental unity" (Farrell, 2006: 25). Its designation and recognition as an interlocutor of the European Union (Who speaks for Europe? Who speaks for Africa?) has significantly enhanced its role and set a pattern for future relations. To consolidate the AU-EU relationship, the European Union appointed, in 2008, a delegation to the African Union and Commission-to-Commission format of talks between the two Unions have become common practice.

The problem, however, remains with the designation of the African Union as a single representative of Africa and as an international actor capable of international acting on its own behalf as well as on behalf of its member states. Indeed, even though the African Union is a much more capable international actor than it was previously, especially in comparison with the Organization of African Unity, its predecessor, the 
lack of its own competences is pretty evident and the process of its capability building is very slow.

For one thing, this is true for the European Union side as well. Since the EU is "a unique, non-traditional and relatively new contender for this status, conceptualizing its international roles, or 'actorness' presents many challenges" (Bretherton, Vogler, 2006: 13). Some of those challenges continue even though the Treaty of Lisbon has explicitly provided, in the new Article 46A, that "The Union shall have legal personality."

Cremona, defining competence in EU external relations comes to the conclusion that the Treaty of Lisbon "perpetuates and even extends a tendency to define new legal bases for different categories of relationship" and that on balance the advantage of such differentiation "is outweighed by the lack of clarity as to what exactly the differences entail, exacerbated by the fact that they are to be found in different places in the Treaties and potential issues of appropriate legal base" (Cremona, 2010: 50). Once again, we need to remind ourselves that the European side of the partnership is fragmented as well and its fragmentation has many different faces. For instance, its competences are divided between the Commission which is responsible for negotiating partnership agreements, the Council of Ministers and bodies dealing with development, economic aid and the European Union's diplomatic relations. Moreover, the European Union (the Foreign Affairs Council of the Council of Ministers) has adopted four different strategies on Africa - one, in 2005, that covers the whole continent and three other strategies that cover particular regions of Africa: Mediterranean, the Sahel and the Gulf of Guinea.

It is not the purpose of this analysis to comment upon external competences of the European Union, but to acknowledge the complexity of its international actorness, the persistence of the expectations-capabilities gap that makes the EU a fragmented international actor and to submit that in comparison with the European Union, the African Union "still has some way to go to attain the level of maturity" (Farrell, 2006: 27). Pease rightly concludes her analysis of the African Union with an observation that "...the idea of Africa as a regional block akin to the EU is a long way off" and that "like many IGOs, the AU is grappling with the simultaneous forces of globalization and fragmentation that are impacting its diverse member states" (Pease, 2019: 33-34).

However, few would deny that Africa is coming of age. That is an expectation Africa has to respond to, especially in times of change, when its partnerships with the European Union are being negotiated Doubts about the success of this project are not to be lightly dismissed. What Africa brings to the negotiating table is both its fragmentation and pan-African unity. On the one hand, it is an array of sub-regional projects and institutions and a network of bilateral arrangements made, among others, with China. There is, on the other hand, the "AU phenomenon," a global institution and actor (see Edozie, 2014). There are pan-African projects and initiatives, such as the EU's pan-African Programme that provides support to the Africa-EU strategic partnership, the first ever EU plan for development and cooperation that covers Africa as a whole. Other developments that have effectively altered the African landscape include, for instance, the African Continental Free Trade Area (AfCFTA) which, quite naturally, will 
be a pan-African partner of the European Union when fully operational. The African Continental Free Trade Area entered into force at the end of May 2019.

The final observation we would like to make in this section is that fragmentation of the African side of the new partnership is, at least for the foreseeable future, quite natural and perhaps even welcome given the still rather limited authority of the African Union to act 'on behalf of Africa' and the enormous size and complexity of the African continent.

The EU and Africa have a long history of mutual relations and partnerships. As this paper has demonstrated, the time has come for their redefinition. The termination of the Cotonou agreement raises a number of fundamental questions about the future of the EU's partnership with Africa and Africa's partnership with Europe. The partnership needs to undergo a profound and rapid change.

It is useful to emphasize that the EU-Africa partnership is a process - ever closer partnership. The historical record of this partnership is closely associated with the Treaty of Rome and a chain of successive agreements - Yaoundé, Lomé and Cotonou. It has passed through three generations which, step by step, added key elements of today's partnership. It has evolved from a relatively limited scale into a comprehensive system of normative instruments and institutions. And it has bifurcated into the EU-ACP and EU-AU partnerships. Though the two partnerships have over the past ten years grown closer, there are still noteworthy differences between the two systems. What is next?

Today, the time is ripe for a new partnership and in fact both partnerships are being re-negotiated. A number of thorny questions have to be addressed in the process: are both partnerships equally important? Should one partnership prevail over the other? Should they merge? If so, on what terms? How can the partnership be enhanced? And, more importantly, does it have a chance to become more than just a 'rhetorical commitment'? The stakes are high and resolve from both parties is required. A variety of circumstances may affect the likelihood of the negotiations being completed successfully. And we will not know the answers anytime soon. Optimistically, by the end of 2020 - "a pivotal year in living up to our ambition of an even stronger partnership with Africa, our natural partner."

Despite many unanswered questions, what is certain is that African actors are increasingly in favour of a 'continent to continent' partnership with the European Union, one which would capitalize on the African Union's Agenda 2063 - the plan to transform Africa into a global power. It is our conclusion that while the ACP partnership will beyond doubt continue, it is only a matter of time, a question of 'when' rather than 'if', the EU-AU or AU-EU partnership is integrated into one comprehensive framework.

Certainly, this will be a fascinating area for future inquiry focusing on how to describe and explain this new multidimensional partnership and on the relevance of the neo-liberal thinking that for so long was used to explain the EU's relations with ACP states (Hurt, 2000; Farrell, 2006). 


\section{REFERENCES}

ACP-EEC Convention (1985), The Courier, http://aei.pitt.edu/37200/1/A2039.pdf, (15.01.2020).

Akokpari J. (2017), The EU and Africa: The Political Economy of an Asymmetrical Partnership, in: The ACP Group and the EU Development Partnership, (eds.) A. Montoute, K. Virk, Palgrave Macmillan, Cham.

Arts K., Dickson A.K. (2009), EU Development Cooperation: From Model to Symbol, Manchester University Press, Manchester.

Bartelt S. (2012), ACP-EU development cooperation at a crossroads-one year after the second revision of the Cotonou Agreement, "European Foreign Affairs Review", Vol. 17, No. 1.

Bretherton C., Vogler J. (2006), The European Union as a Global Actor, Routledge, London-New York.

Carbone M. (2013), Rethinking ACP-EU relations after Cotonou: tensions, contradictions, prospects, "Journal of International Development", Vol. 25, No. 5.

Carbone M. (2018), Caught between the ACP and the AU: Africa's relations with the European Union in a post-Cotonou Agreement context, "South African Journal of International Affairs", Vol. 25, No. 4.

Cremona M. (2010), Defining competence in EU external relations: lessons from the treaty reform process, in: Law and Practice of EU External Relations. Salient Features of a Changing Landscape, (eds.) A. Dashwood, M. Maresceau, Cambridge University Press, Cambridge.

Declaration, African Union-European Union Summit 2017, 29-30 November, Abidjan, https://www. consilium.europa.eu/media/31991/33454-pr-final_declaration_au_eu_summit.pdf.

Elgström O., Pilegaard J. (2008), Imposed coherence: negotiating economic partnership agreements, "European Integration", Vol. 30, No. 3.

Edozie R. K. with Gottschalk K. (2014), The African Union's Africa: New Pan-African Initiatives in Global Governance, Michigan State University Press, East Lansing.

EEAS, Press Release, High Representative/Vice-President Josep Borrell concludes his visit to Ethiopia, 28/02/2020.

European Commission (2020), New Africa-Caribbean-Pacific/EU Partnership: moving forward towards a new partnership fit for the future, Press Release, Brussels 14 February 2020.

European Commission (2020), EU paves the way for a stronger, more ambitious partnership with Africa, Press Release, 9 March 2020.

Farrell M. (2006), A triumph of realism over idealism? Cooperation between the European Union and Africa, in: The EU as a Global Player: The Politics of Interregionalism, (eds.) F. Söderbaum, L. van Langenhove, Routledge, Milton Park-New York.

Frisch D. (2008), La politique de développement de l'Union européenne: un regard personnel sur 50 ans de coopération internationale, Centre Européen de Gestion des Politiques de Développement.

Gruhn I. V. (1976), The Lomé Convention: inching towards interdependence, "International Organization", Vol. 30, No. 2.

Herszenhorn D. (2019), Von der Leyen ventures to the heart of Africa, "Politico" [online], p. 1, https://www.politico.eu/article/european-commission-president-ursula-von-der-leyen-ventures-to-the-heart-of-africa-ethiopia-african-union/ (21.01.2020).

Holland M. (2002), The European Union and the Third World, Palgrave, New York.

Huber S. (2013), Polyphonie sur l'identité de l'Europe communautaire: Aux origines d'un discours (1962-1973), Graduate Institute Publications. 
Hurt S. R. (2004), The European Union's external relations with Africa after the Cold War, in: Africa in International Politics. External Involvement on the Continent, (eds.) I. Taylor, P. Williams, Routledge, London-New York.

Ighobor K. (2013), China in the heart of Africa Opportunities and pitfalls in a rapidly expanding relationship, "Africa Renewal", https:/www.un.org/africarenewal/magazine/january-2013/ china-heart-africa (21.03.2020).

Joint Communication to the European Parliament and the European Council Towards a Comprehensive Strategy with Africa, Brussels 9.3.2020, https://ec.europa.eu/international- partnerships/ system/files/communication-eu-africa-strategy-join-2020-4-final_en.pdf (15.03.2020).

Kaczmarek F. (2019), African Dimension of the Belt and Road Initiative, "Przegląd Strategiczny", Issue 12.

Kingah S. (2006), The revised Cotonou Agreement between the European Community and the African, Caribbean and Pacific States: innovations on security, political dialogue, transparency, money and social responsibility, "Journal of African law", Vol. 50, No. 1.

Kopinski D., Polus A., Taylor I. (2011), Contextualising Chinese engagement in Africa, "Journal of Contemporary African Studies", Vol. 29, No. 2.

Kotsopoulos J. (2017), How 60 year old Treaty of Rome still influences EU, Africa partnership, "Business Daily", https://www.businessdailyafrica.com/analysis/Treaty-of-Rome-EU-Africa-partnership/539548-3871374-wjhw4y/index.html (21.03.2020).

Kotsopoulos J., Mattheis F. (2018), A contextualisation of EU-Africa relations: Trends and drivers from a reciprocal perspective, "South African Journal of International Affairs", Vol. 25, No. 4.

Langan M. (2012), Normative power Europe and the moral economy of Africa-EU ties: a conceptual reorientation of 'normative power', "New Political Economy", Vol. 17, No. 3.

Laporte G. (2012), What future for the ACP and the Cotonou agreement?: preparing for the next steps in the debate, ECDPM (Briefing Note 34), Maastricht.

Lopes C. (2019), Europe needs to make mind up on relations with Africa, EUobserver, https://euobserver.com/opinion/146882 (25.01.2020).

McQueen M. (1998), ACP-EU trade cooperation after 2000: an assessment of reciprocal trade preferences, "The Journal of Modern African Studies", Vol. 36, No. 4.

Montoute A. (2017), Introduction, in: The ACP Group and the EU Development Partnership: Beyond the North-South Debate, (eds.) A. Montoute, K. Virk, Palgrave Macmillan, Cham.

Nielsen N. (2019), Interview. EU Africa Envoy: Europe Needs To Look Beyond Migration, "EUobserver", https://euobserver.com/economic/146657 (22.02.2020).

Orbie J. (2007), The European Union and the commodity debate: from trade to aid, "Review of African Political Economy", Vol. 34, No. 112.

Pease K-K. S. (2019), International Organizations. Perspectives on Global Governance, Routledge, New York-London.

Stevens C. (2006), The EU, Africa and Economic Partnership Agreements: unintended consequences of policy leverage, "The Journal of Modern African Studies", Vol. 44, No. 3.

Storey A. (2006), Normative power Europe? Economic partnership agreements and Africa, "Journal of Contemporary African Studies", Vol. 24, No. 3.

The Africa-EU Strategic Partnership. A Joint Africa-EU Strategy (2007), https://africa-eu-partnership.org/sites/default/files/documents/eas2007_joint_strategy_en.pdf.

Von der Leyen U. (2019), A Union that strives for more. My agenda for Europe. Political guidelines for the next European Commission 2019-2024, https://ec.europa.eu/commission/sites/betapolitical/files/political-guidelines-next-commission_en.pdf(15.03.2020). 
Whiteman K. (2017), A History of the ACP-EU Relationship: The Origins and Spirit of Lomé, in: The ACP Group and the EU Development Partnership. Beyond the North-South Debate, (eds.) A. Montoute, K. Virk, Palgrave Macmillan, Cham.

Young A. R., Peterson J. (2013), 'We care about you, but...': the politics of EU trade policy and development, "Cambridge Review of International Affairs", Vol. 26, No. 3.

Zajączkowki K. (2005), The relations between the European Union and the countries of sub-Saharan Africa following the end of the Cold War, "Hemispheres. Studies on Cultures and Societies", Vol. 20.

Zartman I. W. (2016), Politics of Trade Negotiations between Africa and the European Economic Community: The Weak Confronts the Strong, Princeton University Press.

\begin{abstract}
The European Union has a long history of relations with Africa and Africa has always been a strategic partner for the European Union. Today, however, the European Union's relations with Africa are at a crossroads and the partnership needs to undergo a profound and rapid change. In order to properly investigate this research problem and to address its research questions concerning the future of the EU-Africa partnership, it is demonstrated that the time has come for change and redefinition of the partnership. Therefore, the overall aim of the article is to provide an insight into the EU's new partnership with Africa, to explore its complex, fragmented nature and scope, actors, legal bases, constitutive elements and different ways both sides are going to present the new agreement to their respective constituencies. The way this research is pursued combines a number of methods. It involves textual analysis of primary sources - the instruments regulating the EU's relations with Africa, secondary sources, documentary analysis as well as comparative, contextual and historical analysis. The complexities facing the EU and its African partners encourage curiosity and reflection about the new partnership. The article strongly emphasizes that the EU-Africa partnership does not stand still. It is a process of ever closer partnership. It has evolved from a relatively limited scale into a comprehensive system of normative instruments and institutions. And it has bifurcated into EU-ACP and EU-AU partnerships and today both partnerships are being re-negotiated. The likelihood of the negotiations being completed successfully, optimistically, by the end of 2020, remains open. It is our overall conclusion and prediction that the EU-Africa partnership will be enhanced and move a step closer to an integrated, comprehensive partnership, an effective framework for EU-AU relations.
\end{abstract}

Keywords: European Union, African Union, EU-Africa partnership, Cotonou Agreement

\title{
STOSUNKI UNII EUROPEJSKIEJ Z AFRYKĄ: W KIERUNKU NOWEJ, KOMPLEKSOWEJ STRATEGII Z AFRYKĄ. MIĘDZY SCYLLĄ A CHARYBDĄ
}

\section{STRESZCZENIE}

Unia Europejska ma długą historię stosunków i strategicznego partnerstwa z Afryką. Dziś jednak stosunki Unii Europejskiej z Afryką są na rozdrożu, a ich partnerstwo musi ulec głębokiej i szybkiej transformacji. Aby właściwie zbadać ten problem badawczy i odpowiedzieć na pytania badawcze dotyczące przyszłości partnerstwa Unii Europejskiej z Afryką, artykuł dowo- 
dzi, że nadszedł czas na jego zmianę i redefinicję. Głównym celem tego artykułu jest identyfikacja nadrzędnych ram nowego partnerstwa UE z Afryką, analiza jego elementów konstytutywnych, złożonego charakteru i zakresu, aktorów, podstaw prawnych, i pozycji negocjacyjnych stron nowego partnerstwa. Badania prowadzono z wykorzystaniem wielu metod badawczych, przede wszystkim analizy tekstowej źródeł podstawowych - dokumentów regulujących stosunki UE z Afryką, literatury, analizy dokumentalnej, a także analizy porównawczej, kontekstualnej i historycznej. Trudności przed jakimi stoją negocjatorzy Unii Europejskiej i ich afrykańscy partnerzy, których oczekiwania są często dramatycznie rozbieżne, rodzą ciekawość i refleksję na temat nowego partnerstwa. Autorzy wychodzą z założenia, że partnerstwo Unii Europejskiej z Afryką jest procesem i nie stoi w miejscu. Jest to proces coraz ściślejszego związku, który stopniowo przekształcił się w kompleksowy system instrumentów i instytucji i podzielił się na dwa równoległe partnerstwa - partnerstwo Unii Europejskiej z państwami Afryki, Karaibów i Pacyfiku i partnerstwo Unii Europejskiej z Unią Afrykańską. Oba te partnerstwa są dzisiaj przedmiotem ponownych negocjacji, a prawdopodobieństwo pomyślnego zakończenia negocjacji do końca 2020 roku pozostaje zdaniem autorów pod znakiem zapytania. Niemniej jednak naszym ogólnym wnioskiem i prognozą jest, że partnerstwo Unii Europejskiej z Afryką zostanie wzmocnione i zbliży się o krok do zintegrowanego, kompleksowego partnerstwa i skutecznych ram dla stosunków Unii Europejskiej z Unią Afrykańską.

Słowa kluczowe: Unia Europejska, Unia Afrykańska, partnerstwo Unii Europejskiej z Afryką, Umowa z Cotonou 